\title{
The Effect of Managerial Ownership, Covenant Debt and Litigation Risk on Accounting Conservatism
}

\author{
Dirvi Surya Abbas ${ }^{1}$, Tubagus Ismail ${ }^{2}$, Muhamad Taqi ${ }^{3}$, Helmi Yazid $^{4}$ \\ University of Sultan Ageng Tirtayasa, University of Muhammadiyah Tangerang ${ }^{1}$, University of \\ Sultan Ageng Tirtayasa ${ }^{2,3,4}$ \\ \{abbas.dirvi@gmail.com\}
}

\begin{abstract}
We looked at the impact of managerial ownership, debt covenants, and litigation risk on accounting conservatism. This study's population includes 12 consumer products manufacturing companies registered on the Indonesia Stock Exchange in 2015-2018. Purposive sampling was employed to choose the study's sample companies. The data is secondary. Panel data regression analysis was used to analyze the data. Accounting conservatism is positively influenced by managerial ownership and lawsuit risk. Accounting conservatism is not affected by differing loan covenants. The results of this study show that management's financial reporting conservatism is unaffected by debt arrangements. In any case, the debt agreement should encourage management to enhance its financial reporting. If not, the agreement sanctions the management. Of course, this finding should help economic knowledge, particularly in accounting and finance.
\end{abstract}

Keywords: Managerial Ownership, Debt Covenant, Litigation Risk, Accounting Conservatism

\section{Introduction}

According to researchers [1]-[3] stated that the Financial Accounting Standards Board (FASB) provides freedom for management in choosing conservative accounting methods used in preparing the company's financial statements. Therefore, the preparation of financial statements must be based on the basic principles of financial statements, one of which is the precautionary principle called conservatism. This principle assumes that the company will face economic uncertainty in the future. Furthermore, this flexibility affects the behavior of managers in accounting and reporting company financial transactions.

Many cases occur due to this flexibility due to the freedom of management to make financial statements with conservative principles. [1], [4], [5] revealed that if the financial statements are made on a conservative basis the results tend to be biased and do not reflect the actual financial condition of the company. The case of manipulation of financial statements was carried out by the Toshiba Corporation. One of the cases of accounting conservatism is the case of a financial statement scandal. Included in the internal accounting scandal in May 2015.

The chief executive officer (CEO) of Toshiba Corp, namely Tanaka and other senior officials resigned because of their involvement in the accounting scandal in Japan. The company's management is known to set unrealistic profits so that when the target is not achieved, the company is forced to manipulate the financial statements in accordance with the targeted profit. The results of the investigation showed that Tanaka was proven to be aware of the manipulation of the financial statements of USD 1.22 billion [6]. This information shows 
the beginning of the collapse of the Toshiba company's economic reputation. This is based on the existence of an overstatement of profits made by the management.

This action is certainly contrary to the principle of accounting conservatism. where in practice, accounting conservatism is to recognize profits by prioritizing prudence and will be recorded in the books when the transaction has actually been realized. Based on media information, which broadcast information about the results of investigations into cases of profit overstatement in the company, not a few also stated that from several cases the management and top management divisions played a role and deliberately suppressed accrual costs that should be charged in the next period. But in fact, the management pulls this information into the current period.

Conservatism can be explained by using agency theory. In agency theory, it is explained about the separation of interests between management and company owners. In reality, this often creates a conflict of interest so that it affects the company's performance and results in the quality of the company's reported earnings. In relation to agency theory, it is explained that when one or more leaders employ management in order to carry out a service and then delegate authority in making decisions to the management.

The relationship between company owners and management can lead to asymmetric information conditions because management is in a position that has more information about the company than the owners. Assuming that each individual will act to enrich themselves, then with the information asymmetry owned by the management, of course it will encourage management to hide some information that is not known to the owner. [7]-[9] revealed that shareholders or managerial ownership are company owners who are only interested in the results of increasing profits in the company. while managers are considered only part of the company that can only receive satisfaction from their performance results through bonuses and conditions that accompany the agreement in the company [10]-[12].

The agency relationship is a relationship that arises because of a contract that is applied between company owners or shareholders who use management to launch services whose profits will become the rights of the company owners, based on this, it is necessary to separate ownership and supervision from third parties [13]. [1], [14]-[16] revealed that conflicts of interest between investors and creditors will occur in the practice of conservatism. Furthermore, this is because investors are trying to take advantage of creditor funds through engineering irrelevant dividend payments, asset transfers, asset acquisition and asset replacement. Meanwhile, creditors have an interest in the security of their funds which are expected to generate profits for themselves in the future [17]-[19]..

There are several factors that influence management to act conservatism, including managerial ownership. As stated [1], [2], [4], [14], [20] in the results of his research stated that if managerial ownership is small, the agency problems that arise will be greater, thus the demand for conservative financial statements will be increasingly increased [10], [19], [21], [22]. This statement is supported by the results of previous studies that have been conducted regarding managerial ownership in influencing the level of conservatism, namely by [5], [23] which states that managerial ownership affects accounting conservatism. However, in contrast to the results of research conducted by, [24], [25], they argue that managerial ownership has no effect on accounting conservatism.

This proves that the managerial ownership variable on accounting conservatism still has a gap because it still has the uncertainty of previous research results. In addition to the problem of the lack of managerial ownership, which encourages the increasing demand for conservative financial statements. Managers in responding to violations of debt agreements that have matured, will try to avoid poor performance by carrying out accounting conservatism which will 
later benefit him [11], [26], [27]. Whereas debt covenants explain how management responds and reacts to the debt agreements it manages [7].

So that creditors are not harmed by management's treatment which will later take actions of accounting conservatism, a long-term debt contract (debt covenant) emerges, this contract is an agreement used to protect creditors' rights to avoid management actions that carry out accounting conservatism in in its financial statements, such as excessive dividend distribution, or leaving equity below a predetermined level [8], [9]. In addition, [28] in his research stated that the content of long-term debt contracts (debt covenants) is about agreements that can protect creditors' rights in the future from the actions of managers against their interests in the future. Research [3], [25], [29] stated that leverage as a proxy for long-term debt contracts (debt covenants) has a negative effect on accounting conservatism, but it is different from the results of research [3], [11], [30] which stated that leverage has a positive and significant effect on accounting conservatism.

However, it is different from the results of research conducted by [1], [28], [31] which state that leverage has no effect on accounting conservatism. This proves that the variable of longterm debt contracts (debt covenants) on testing the variable of accounting conservatism as the dependent variable also has not found consistent results, because there are still gaps or there is still no uncertainty from the results of previous research

In addition to the lack of managerial ownership and the existence of fraud in dealing with debt covenants. Factors regarding litigation risk, can also influence management in carrying out accounting conservatism actions. Although litigation factors are external factors, these factors can encourage management to report company finances to be more conservative [27], [32][36]. Management motivation to apply accounting conservatism will be stronger, if the risk of litigation threat to the company is relatively high [30], [36]. Management views that litigation risk is a risk that has the potential to cause quite material costs because it will later be related to legal regulations [32], [33], [37].

Managers will rationally avoid losses due to litigation by reporting financially conservatively, because earnings that are too high have a higher potential litigation risk [38]. According to [34], [39] in his research results stated that the litigation risk variable can have a positive influence on the accounting conservatism variable. However, it is different from the results of research conducted by [4] which states that litigation has no effect on accounting conservatism. This proves that the litigation factor variable on accounting conservatism still has a gap due to the lack of previous research results.

The motivation of this research is because there are still some problems found in the field, and there are still differences from the results of previous studies. The following are some of the motivations for this research, namely. First, there are still companies that have not fully implemented the principle of conservatism, so that their company's financial statements are biased from the real reality, especially companies located in Indonesia where, every company that has large assets, has its own accounting standard reference guidelines. This will certainly make it easier for them to be able to manipulate accounting data for personal interests, and result in financial statements that become irrelevant and reliable, and harm users of financial statements, especially investors and creditors.

Second, the weak supervision of managerial ownership in the company's financial reporting process so that management can easily manipulate data. Third, there are still violations of debt agreements that have matured, this is allegedly due to the lack of supervision from the government on debt covenants. Fourth, management's concern in dealing with litigation risk, when the company's profits are at a gain that is too high, forces them to carry out accounting 
conservatism, because rationally management will think that earnings that are too high will have a higher risk of litigation as well. This will eventually lead to losses.

This research is later expected to add and become knowledge for economics, especially in the field of accounting as an example of a case study that will be used as a reference or benchmark for further researchers and in the world of lectures and can enrich theories and concepts for those in need. In addition, this research is expected to be able to provide an overview to managers about the factors that need to be considered in applying conservative accounting principles.

\section{Literature and Hypothesis}

\section{Agency Theory}

The principal and the agent have different interests in agency theory [13]. The agency theory is based on the contractual connection between owners and managers. Due to opposing interests between management and corporate owners, this idea states that owners and management will never share the same purpose.

Managerial connections develop when one or more business owners hire others to perform a service and then assign decision-making authority to management. The connection between owners and management can lead to asymmetric information situations, when management knows more about the company than the owner. Assuming people behave in their own best interests, the information asymmetry they have will motivate management to keep some facts hidden from the person.

[10], [18], [19], [22], [36] reveal that shareholders as owners of the company are assumed to be only interested in the results of increased financial profits in the company. while the management who is given the authority is assumed to receive a satisfaction result in the form of bonuses and other conditions that accompany the relationship. According to [1], [11], [20], [24], [25] in positive accounting theory, there are three agency relationships, namely:

a. Management relationship with owners (shareholders).

Management will tend to apply less conservative or optimistic accounting if the share ownership in the company is lower than the share ownership of external shareholders. Management wants their performance to be considered good so they will get a bonus (bonus plan motive), then management tends to increase profits for the current year period. However, the owner of the company only wants the realization of dividends and capital gains from the shares they own. Conversely, if the manager's ownership is higher than that of external shareholders, then management tends to report more conservative earnings. The existence of a high sense of belonging from managers to the company makes management more willing to enlarge the company. The application of conservative accounting causes a large enough hidden fund reserve to be able to increase the company's investment. The asset will be recognized at the lowest value, so that the market value is greater than the book value and goodwill is formed. b. Management relationship with creditors.

If the company's debt to equity ratio is high, it is possible for managers to choose conservative accounting methods or those that tend to reduce profits. This is because creditors can oversee management's operational activities, so it asks management to report conservative profits for the safety of their funds.

c. Management relationship with the government.

Managers will tend to report earnings conservatively or cautiously to avoid tighter scrutiny from governments, securities analysts and the public. Large companies will be highlighted by 
these parties more than small companies. Large companies must be able to provide better public services and social responsibility to the community as demanded from the government and also pay higher taxes in accordance with high corporate profits.

Agency theory In addition to explaining the existence of management conflicts with company owners, it turns out that there are other factors that make management conflicts with company owners appear in the company, namely the creation of several management behaviors by using the authority they have in accordance with their wishes. [40] This relates to the relationship between agency theory and managerial ownership variables on accounting conservatism.

This study uses agency theory, because accounting conservatism is related to financial statements which can lead to agency problems between management and company owners [41]. The emphasis of agency theory is on the independent variables used in this study, namely managerial ownership and debt covenants which are proxied by leverage, which are thought to affect the conservatism of a company's financial statements.

In managerial ownership variables related to agency which means that between management and company owners as well as management and creditors will have different objectives which result in the company choosing to record financial statements by applying the principles of accounting conservatism. According to [42] the existence of management motivation in the use of accounting conservatism, contained in the explanation in positive accounting theory. The three hypotheses that motivate management to carry out accounting conservatism are because. First, the bonus plan hypothesis. second, the debt covenant hypothesis, and third, the political cost hypothesis.

According to [12], [43] states that by showing good performance in the financial statements to creditors, the company will easily borrow funds because in a high profit situation, creditors will believe that the company is able to cover its debts and believe that the company can reduce its debts. the level of risk of unpaid debt.

\section{Accounting Conservatism}

According to [44], [45] accounting conservatism causes the write-off of unrealized losses due to losses, immediately after the recognition of gains when a loss is possible, but gains from increasing the value of the company cannot be recognized until the recognition has actually been realized. In addition, accounting conservatism can provide a signal for management's confidence in the company for the future [46], [47]. Uncertain company conditions can affect the choice of accounting method used so that the results of the presentation of financial statements will be different in each company.

Accounting conservatism includes the use of more appropriate standards to recognize bad news indicating that the company is experiencing a loss and good news to indicate that the company is experiencing a profit, besides being useful as a medium in facilitating efficient contracts between management and company leaders.

\section{Managerial ownership}

Management who has managerial ownership in the company and also doubles as the owner of the company, will be able to quickly align their interests [1], [2], [4], [14], [20]. However, this will be different if the management does not double as the owner of the company, the possibility that will happen is that the management has a motive only to be concerned with his personal interests as a manager in the company where he works. The benefits of having managerial ownership in the company, aligning the interests of management with the owners of the company, so that management can directly feel the benefits of the profits obtained based on 
relevant decisions and will bear the losses as a consequence, based on less reliable decision making.

The assumption of problems that arise in agency theory will disappear, if a manager can position himself as an owner of the company. This reason indicates the importance of managerial ownership in the ownership structure of the company. If it is associated with accounting conservatism, managerial ownership structure has an influence on managerial incentives and prudence in reporting. The low managerial ownership structure can affect the possibility of inadvertence in financial reporting that can be carried out by management.

\section{Debt Covenant}

Debt covenants are contracts aimed at borrowers by creditors to limit activities that may violate the agreed loan agreement so that the loan can be returned to the creditor without problems. The debt agreement partially contains an agreement that requires the borrower to immediately comply with the written and agreed terms in the debt agreement. Long-term debt covenants (debt covenants) as an agreement to protect lenders (credit) from actions that violate management's rights to creditors, such as excessive dividends, or allowing the working capital and wealth of the company owner to be below a healthy standard level. according to a predetermined agreement, which can reduce the risk (or increase the risk) to the creditor [11], [26], [48].

Furthermore, according to [28] stated that the occurrence of a violation of the agreed debt agreement, resulted in the emergence of a cost and could hamper management's performance, therefore, management will try to prevent or minimize fraudulent actions. If the company experiences financial difficulties, it will automatically be considered a breach of contract which results in credit irregularities and expenses [8]. Debt covenants predict that managers want to increase profits and assets to reduce debt contract costs, when the company terminates its debt agreement [42]. In accordance with research [1], [28], [49] which states that leverage is a proxy for the company's tendency to violate contractual agreements. If the company has been given a loan by the creditor, the creditor automatically has an interest in the certainty of the return of the funds that have been lent and it is expected that in the return of the loan there is a profit difference.

According to [50], creditors in protecting their rights from management actions that may harm creditors, they will use them by way of the terms proposed in the credit agreement, in the sense that if creditors think that the company is trying to take advantage of them in an unethical way, then they will either stop further lending or the lending is done at a higher than normal cost of borrowing.

\section{Risk Litigation}

Lawsuit risk is defined as the inherent risk in a business that allows for the threat of litigation by dissatisfied parties with an interest in the business[27], [32]-[36]. Creditors, investors, and regulators are all stakeholders having an interest in the company. From the creditor's perspective, the possibility of litigation occurs when the corporation fails to carry out the contract's terms, such as its failure to pay agreed-upon obligations.

Meanwhile, the possibility of litigation occurs on the investor side as a result of the company's operations, which result in investor losses as represented in price movements and share volume. 


\section{Managerial Ownership Relationship with Accounting Conservatism}

Managerial ownership is the proportion of common stock owned by management. With managerial ownership, it can motivate management to maximize its performance in the form of achieving profit targets. When management has motivation to improve company performance, management will be more conservative in determining accounting policies. The results of the research [5], [23] stated that managerial ownership has an influence on accounting conservatism.

According to the results of research [14], it is interpreted that the company will be more stringent in applying conservative accounting principles if the majority share ownership comes from management. The existence of a sense of ownership makes management not only think about bonuses that will be obtained if the profits are high, but management will also be more concerned with the continuity of the company in the long term and developing the company.

The statement from [3] indicates that if management has a large shareholding, then management will be more likely to report the company's earnings conservatively, because it is based on management's sense of ownership of the company tends to be larger so that management is willing to enlarge the company by using retained earnings. , which can increase the amount of investment. The market value of the company will be greater than the book value because the asset value is recognized by the company with the lowest value. Therefore, the market and investors will evaluate this positively.

Previous research conducted by [5], [23] showed that managerial ownership structure has a positive effect on accounting conservatism. which states that the higher the managerial ownership in the company, the less conservative the financial statements. However, this is different from the results of research conducted by [4], [25], [30] which state that if managerial ownership is small, the agency problems that arise will be even greater, thus the demand for conservative financial statements will increase. This proves that the size of the shares owned by management is related or can affect conservatism in financial reporting. Therefore, the research hypothesis proposed are as follows:

$H_{1}$ : Managerial ownership have a positive affect on accounting conservatism

\section{The Debt Covenant's Relationship with Accounting Conservatism}

Debt covenant is a debt contract that is proxied by leverage. Leverage itself is a ratio that calculates how much the company's assets can guarantee a company's liability. With the debt covenant, the management will get a lot of assets that come from loan funds provided by creditors. This loan will also show management's ability to manage all company assets. Creditors will pay close attention to financial information from the policies used in preparing financial reports for credit applications.

Management is expected to be careful in disclosing the value in each account in the financial statements, because creditors will pay close attention to the information presented. Thus, debt covenants affect accounting conservatism. This explanation is in line with the results of research conducted [3], [14], [25], [28], [29]. Therefore, the research hypothesis proposed is as follows:

$\mathrm{H}_{2}$ : Debt covenants have a negative effect on accounting conservatism.

\section{Litigation Risk Relationship with Accounting Conservatism}

Litigation risk is an inherent risk in a business that allows for threats from third parties having an interest in the business who are offended[51]. Litigation risk is a risk that has the potential to result in significant costs if you are later confronted with legal issues. Management 
would rationally limit legal losses by reporting conservatively, as a pretty significant profit will also carry a high chance of litigation[52].

When a firm earns a lot of money and distributes a lot of dividends while paying down debt, the lawsuit risk is considerable. Creditors will sue the company to collect on these debts. [38] argued that management will be more driven to follow the conservative principle in order to expedite the recognition of the company's obligations, hence minimizing the profit presented by the company and avoiding a significant litigation risk.

[27], [32]-[34], [36], [53] stated that the company will always try to avoid litigation or lawsuits, because when a company is caught in a legal problem, not only will there be additional costs incurred, but also will damage the company's reputation, resulting in management to be more conservative in its accounting reporting. In addition, to maintain its viability, the company will tend to minimize the risks that may occur. Based on positive accounting theory in an effort to reduce litigation risk, management through financial statements will provide a positive signal to investors, by providing quality earnings and applying the principle of conservatism.

This positive signal can give investors' confidence in management in improving the company's performance. If the financial statements give a negative signal, then the possibility of litigation risk from parties who feel aggrieved will be higher and lead to high litigation costs as well. Previous research according to [34], [39], [51] litigation risk has an effect on accounting conservatism. In a very strict legal environment, the tendency of managers to report financially conservatively is getting higher. Management's encouragement to apply accounting conservatism will be stronger if the risk of litigation threats to the company is relatively high. High litigation risk stems from high corporate profits, so that the dividends distributed will be high and debt payments will be low, then creditors will sue the company for paying the debt [24].

Managers will be more motivated to apply the principle of conservatism by accelerating the recognition of the company's debt, so that the profit presented is not high so that the company can avoid high litigation risk. From this explanation, it is found that litigation risk has a positive effect on accounting conservatism, meaning that the greater the litigation risk that occurs in the company, the greater the application of accounting conservatism. Therefore, the research hypothesis proposed is as follows:

$H_{3}$ : Litigation risk has a positive effect on accounting conservatism

\section{Methodology}

\subsection{Research Design, Population and Sampling Procedure}

This research is quantitative in nature because it utilizes data derived from the company's yearly financial statements, which contain numerical data. The issue formulation used in this study is an example of an associative problem having a causal relationship. This study uses samples from manufacturing sector companies listed on the Indonesia Stock Exchange (IDX) from 2015 to 2018 .

The following are the sample selection stages that have been carried out: Manufacturing sector (Consumer Good) companies listed on the IDX in 2015-2018, which are 57 companies. There were 18 companies that did not consistently publish complete and routine financial reports on the IDX's official website during the 2015-2018 period. Furthermore, there are 16 companies that do not have a managerial ownership structure.

Then, there were 11 companies that did not consistently publish financial reports in rupiah currency on the IDX's official website during the 2015-2018 period. Based on the sample data 
selection process carried out, a sample of 12 companies from manufacturing companies in the consumer goods industry sector were obtained which will be studied for a period of 4 years starting from 2015-2018. So that the number of research sample data obtained is as many as 48 data.

\section{Measurement of Variables}

Table 1. Variable Operational Definition

\begin{tabular}{|c|c|c|c|}
\hline No & Variable & Indicator & Scale \\
\hline 1. & $\begin{array}{c}\text { Accounting } \\
\text { Conservatism }(Y)\end{array}$ & $\begin{array}{c}\text { Book to market ratio }\left(C O N \_M K T\right)= \\
\frac{\text { Equity to book value }}{\text { Closing price } x \text { volume shares }}(1)\end{array}$ & Ratio \\
\hline 2. & $\begin{array}{c}\text { Managerial } \\
\text { Ownership }\left(X_{1}\right)\end{array}$ & $\begin{array}{c}\text { Kepemilikan manajerial }= \\
\frac{\text { Jumlah Saham yang dimiliki manajemen }}{\text { jumlah saham yang beredar }}\end{array}$ & Ratio \\
\hline 3. & Covenant Debt $\left(X_{2}\right)$ & $\mathrm{DAR}=\frac{\text { Total Debt }}{\text { Total Assets }}(3)$ & Ratio \\
\hline 4. & Litigation Risk $\left(X_{3}\right)$ & $\frac{\text { Aset jangka pedek-liabilitas jangka pendek }}{\text { total aset }}$ & Ratio \\
\hline
\end{tabular}

Source: E-views 10.0, the data is processed (2021)

The analytical method that was utilized to examine the data acquired as well as to test the hypotheses suggested in this study is Descriptive statistics are statistics that are used to assess data by summarizing or describing the data that has been acquired as it is without the goal of drawing conclusions or generalizing that apply to the wider audience. Descriptive statistics describe or portray data based on the average value (mean), median, mode, standard deviation, maximum, and minimum, resulting in clear and understandable information. Following the results of the descriptive statistics tests, the next step is to test the selection of panel data regression models.

The panel data regression approach is used in this study. The table below highlights the test findings used to select the optimal regression analysis model for this investigation.

\section{Result and Discuss}

Table 2. Model Estimation Test Results

\begin{tabular}{l|c|c|c|c}
\hline \multicolumn{1}{c|}{ Effect Test } & Prob>F & \multicolumn{3}{|c}{ Best Model } \\
\cline { 3 - 5 } & & Determining test & $\begin{array}{c}\text { (Prob>F) / } \\
\text { (Prob>Chibar2) / } \\
\text { (Prob>Chi2) }\end{array}$ & Description \\
\hline $\begin{array}{l}\text { Ordinary Least } \\
\text { Square (OLS) }\end{array}$ & 0.0000 & Chow test (OLS vs FE) & 0.0000 & Fixed Effect \\
\hline Fixed Effect (FE) & 0.0000 & Hausman test (FE vs RE) & 0.8345 & $\begin{array}{c}\text { Random } \\
\text { Effect }\end{array}$ \\
\hline $\begin{array}{l}\text { Random Effect } \\
\text { (RE) }\end{array}$ & 0.0000 & LM test (OLS vs RE) & 0.0000 & $\begin{array}{c}\text { Random } \\
\text { Effect }\end{array}$ \\
\hline Adjusted R-squared & & \multicolumn{3}{c}{0.292463} \\
\hline F-Statistic & \multicolumn{4}{c}{7.475878} \\
\hline Prob(F-statistic) & \multicolumn{4}{c}{0.000378} \\
\hline
\end{tabular}


Based on the results of the three tests that have been carried out, it can be concluded that the Panel Data Regression Model that will be used to determine the effect of managerial ownership, covenant debt and litigation risk on accounting conservatism is the Random Effect Model (REM). With the selection of the Random Effect Model as the panel data regression model to be used, it is not necessary to do the Blue Test Result Test in this study. Here are the results of the Random Effect Model (REM)

Table 4. Research's Hypotheses Test Results

\begin{tabular}{|c|c|c|c|c|c|}
\hline Hyp. & Hypothesis Statement & Coef. Value & $\mathbf{P}>|\mathbf{z}|$ & Sig & Model \\
\hline 1. & $\begin{array}{l}\text { Are Managerial Ownership have } \\
\text { positive affected to Accounting } \\
\text { Conservatism }\end{array}$ & 2.68230 & $\begin{array}{l}\text { Hypothesis } \\
\text { accepted }\end{array}$ & $\sqrt{ }$ & \multirow{3}{*}{$\begin{array}{c}\text { Market To Book } \\
\text { Ratio }=4.786389 \mathrm{~K} \\
+0.676213 \mathbf{M A N}- \\
2.416853 \mathrm{DAR}- \\
4.906341 \mathrm{RL}+\mathcal{E}\end{array}$} \\
\hline 2. & $\begin{array}{l}\text { Are Debt Covenant have negative } \\
\text { affected to Accounting } \\
\text { Conservatism. }\end{array}$ & -1.58824 & $\begin{array}{c}\text { Hypothesis } \\
\text { denied }\end{array}$ & - & \\
\hline 3. & $\begin{array}{l}\text { Are Litigation Risk have positive } \\
\text { affected to Accounting } \\
\text { Conservatism }\end{array}$ & -2.46598 & $\begin{array}{l}\text { Hypothesis } \\
\text { accepted }\end{array}$ & $\sqrt{ }$ & \\
\hline
\end{tabular}

Source: E-views 10.0, the data is processed (2021)

\section{The effect of Managerial Ownership between Accounting Conservatism}

The test results regarding the managerial ownership variable are declared to have an effect on the accounting conservatism variable which shows that the results of the t-statistic value of the managerial ownership variable have a positive and significant effect. it can be seen from the t-statistic value of 2.682302, which is greater than the t-table value of 2.060 and the value of Prob. of 0.0103 is smaller than the significant level, which is equal to 0.05 and it can be concluded that Hypothesis 1 can be accepted in this study. These results are in accordance with research [5], [23] which states that managerial ownership variables have an effect on Accounting Conservatism.

Based on the results of data calculations and confirmation to management who have managerial ownership in one of the companies in Indonesia, it is stated that managerial ownership in Indonesia has an understanding of the functions, duties and responsibilities that are still varied, thus triggering managerial ineffectiveness in carrying out their assigned tasks. In the end, it can lead to not realizing the quality of the company's performance. As stated [1], [2], [4], [14], [20] in the results of his research stated that if the managerial ownership is small, the agency problems that arise will be even greater, thus the demand for conservative financial statements will increase. increase.

In addition, there are still many companies in Indonesia whose managerial ownership does not only work in one company, but also works for several companies, resulting in managerial ownership not being able to work efficiently and effectively which results in non-conservative financial statements. This is in line with the results of research conducted by, [24], [25], they argue that managerial ownership has no effect on accounting conservatism.

\section{The effect of Debt Covenant between Accounting Conservatism}

The test results regarding the debt covenant variable are declared to have no effect on the accounting conservatism variable which shows that the t-statistic value of the debt covenant variable has a negative and insignificant effect. it can be seen from the t-statistic value which is -1.588244 , which is smaller than the t-table value of 2.060 and the value of Prob. of 0.1194 is greater than the significant level, which is equal to 0.05 and it can be concluded that Hypothesis 
2 is rejected in this study.

These results are in accordance with research [1], [28], [31] which state that leverage has no effect on accounting conservatism. This proves that the variable of long-term debt contracts (debt covenants) on testing the variable of accounting conservatism as the dependent variable also has not found consistent results, because there are still gaps or there is still no uncertainty from the results of previous research. However, the results of this study are different from the results of research conducted by [3], [25], [29] state that leverage is proxied as a long-term debt covenant (debt covenant) has a negative effect on accounting conservatism, but it is different from the results of research [3], [11], [30] which states that leverage has a positive and significant effect on accounting conservatism.

\section{The effect of Litigation Risk between Accounting Conservatism}

The test results regarding the litigation risk variable are declared to have an effect on the accounting conservatism variable which shows that the t-statistic value of the litigation risk variable has a negative and significant effect. it can be seen from the value of t-statistic which is -2.465984 smaller than t-table 2.060 and the value of Prob. of 0.0176 is smaller than the significant level, which is equal to 0.05 and it can be concluded that hypothesis 3 can be accepted in this study.

These results are in accordance with research [34], [39] in the results of his research stating that the litigation risk variable can have a positive influence on the accounting conservatism variable. It said that the supervision that should be carried out by Litigation Risk has not been carried out optimally, especially in preventing activities that harm the company, meanwhile the costs incurred to finance litigation risk continue to be carried out. So that costs are not accumulated efficiently and effectively. However, it is different from the results of research conducted by [4] which states that litigation has no effect on accounting conservatism.

\section{Conclusion}

Based on the results of data analysis that has been carried out in testing the results of research on the effect of managerial ownership, debt covenants and litigation risk on accounting conservatism, it can be concluded that the managerial ownership variable has an influence on accounting conservatism. The results of this study indicate that companies with high managerial ownership do not choose to use the principle of conservatism to avoid a decline in stock prices, because the stock value will decrease if investors are not interested in investing in the company.

To lure investors, companies must have high profits. and litigation risk has an influence on accounting conservatism, this is because the supervision that should be carried out by litigation has not been carried out optimally, especially in preventing activities that harm the company. However, debt covenants have no effect on accounting conservatism. The results of this study indicate that the company does not increase the company's profit to reduce the possibility of terminating debt agreements and financial statements.

The limitations of the results of this study are that this study only uses three independent variables, namely Managerial Ownership, Debt Covenant, and Litigation Risk, which cannot be used as a definite reference for the basis of decision making. Then, Adjusted R-Squared with a value of 0.292463 shows that the influence of the independent variable on the dependent variable is still relatively weak.

Then, the number of sample data is only 48 data consisting of 12 companies with an observation period of 4 years. And the companies that are sampled in this study only come from 
the manufacturing sector of the consumer goods industry sector so that the results cannot reflect other sector companies more broadly.

\section{Theoretical and Practical Contributions}

Based on the conclusions and limitations described above, several recommendations can be given by the researcher, namely, for other researchers, the results of this study can be used as a reference to increase knowledge in conducting research on managerial ownership, debt covenants and litigation risks against conservatism. accountancy. Then, for investors, it is better for investors to invest in companies considering the factors of managerial ownership structure, and debt covenants.

Then, investors can consider the factors that influence the application of accounting conservatism in making investment decisions. Then, the company pays more attention to the percentage of managerial ownership in the company, in order to maintain the independence of effective, precise, and fast decision making. and, for the stakeholders, the results of this study can be used as a source of knowledge and broaden their knowledge about what factors influence accounting conservatism in manufacturing companies in the consumer goods industry sector.

\section{References}

[1] D. Abbas, I. G. Siregar, And Basuki, "Integrity Of Financial Statements And The Factors," $J$. Account. Sci., Vol. 5, No. 1, Pp. 18-28, 2021.

[2] D. Brilianti, Pengaruh Kepemilikan Manajerial, Kepemilikan Institusional, Leverage, Dan Komite Audit Terhadap Konservatisme Akuntansi. 2013.

[3] N. K. S. L. Dewi And I. K. Suryanawa, "Pengaruh Struktur Kepemilikan Manjerial, Leverage, Dan Financial Distress Terhadap Konservatisme Akuntansi," E-Jurnal Akunt. Univ. Udayana, Vol. 7, No. 1, Pp. 223-234, 2014.

[4] M. O. E. Sinambela And L. S. Almilia, "Faktor-Faktor Yang Mempengaruhi Konservatisme Akuntansi,” J. Ekon. Dan Bisnis, Vol. 21, No. 2, Pp. 289-312, 2018.

[5] A. Rahmawati, "The Effects Of Managerial Ownership, Leverage, Dividend Policy In Minimizing Agency Problem,” Invest. Manag. Financ. Innov., Vol. 15, No. 4, Pp. 273-282, 2018.

[6] Integrity, "Skandal Keuangan Perusahaan Toshiba," Integrity-Indonesia, 2017. [Online]. Available: Https://Www.Integrity-Indonesia.Com/Id/Blog/2017/09/14/Skandal-Keuangan-PerusahaanToshiba/.

[7] A. Noviyanti, M. Z. Hakim, And D. S. Abbas, "Pengaruh Debt Covenant, Ukuran Perusahaan, Leverage, Terhadap Konservatisme Akuntansi," In Prosiding Seminar Nasional Ekonomi Dan Bisnis, 2021, Pp. 352-358.

[8] A. Sapitri, M. Z. Hakim, And D. S. Abbas, "Pengaruh Leverage, Ukuran Perusahaan, Intentitas Modal, Debt Covenant, Dan Profitabilitas Terhadap Konservatisme Akutansi," In Prosiding Seminar Nasional Ekonomi Dan Bisnis, 2021, Pp. 389-403.

[9] S. Suhaeni, M. Z. Hakim, And D. S. Abbas, "Pengaruh Debt Covenant, Ukuran Perusahaan, Profitabilitas, Likuiditas, Dan Leverage Terhadap Konservatisme Akuntansi (Pada Perusahaan Sektor Aneka Industri Yang Terdaftar Di Bursa Efek Indonesia Tahun 2016-2019)," In Prosiding Seminar Nasional Ekonomi Dan Bisnis, 2021, Pp. 500-513.

[10] L. Enache, "Board Composition And Accounting Conservatism: The Role Of Business Experts, Support Specialist And Community Influentials," Aust. Account. Rev., Vol. 29, No. 1, Pp. 252-265, 2019.

[11] I. S. A. Bakar, "Board Monitoring And Covenant Restrictiveness In Private Debt Contracts During The Global Financial Crisis," Account. Financ., Vol. 60, Pp. 661-692, 2020. 
[12] I. Iwasaki, "Corporate Ownership And Managerial Turnover In China And Eastern Europe: A Comparative Meta-Analysis," J. Econ. Bus., Vol. 111, 2020.

[13] C. Jensen And H. Meckling, "Theory Of The Firm: Managerial Behavior, Agency Costs And Ownership Structure I . Introduction And Summary In This Paper Wc Draw On Recent Progress In The Theory Of ( 1 ) Property Rights , Firm . In Addition To Tying Together Elements Of The Theory Of E," Vol. 3, Pp. 305-360, 1976.

[14] C. Oktomegah, "Faktor-Faktor Yang Mempengaruhi Penerapan Konservatisme Pada Perusahaan Manufaktur Di Bei," J. Ilm. Mhs. Akunt., Vol. 1, No. 1, Pp. 36-42, 2012.

[15] M. Kang, "Gender Differences In The Relationship Between Land Ownership And Managerial Rights: Implications For Intrahousehold Farm Labor Allocation," World Dev., Vol. 125, 2020.

[16] I. K. Khurana, "International Mergers And Acquisitions Laws, The Market For Corporate Control, And Accounting Conservatism," J. Account. Res., Vol. 57, No. 1, Pp. 241-290, 2019.

[17] S. O'callaghan, "Earnings Management And Managerial Ownership In Private Firms," J. Appl. Account. Res., Vol. 19, No. 4, Pp. 648-668, 2018.

[18] S. D. Dyreng, "Earnings Management To Avoid Debt Covenant Violations And Future Performance," Eur. Account. Rev., 2020.

[19] P. Kumar, "Ownership Structure, Corporate Governance And Institutional Environment: Going Beyond Managerial Opportunism And The Principal-Agent Framework," Corporate Governance: An International Review, Vol. 26, No. 2. Pp. 82-83, 2018.

[20] M. F. Basheer, "The Paradox Of Managerial Ownership And Financial Decisions Of The Textile Sector: An Asian Market Perspective,” J. Soc. Sci. Res., Vol. 2018, Pp. 184-190, 2018.

[21] S. Utomo, "The Moderating Effects Of Managerial Ownership On Accounting Conservatism And Quality Of Earnings," Acad. Account. Financ. Stud. J., Vol. 22, No. 6, 2018.

[22] A. Hajawiyah, "The Effect Of Good Corporate Governance Mechanisms On Accounting Conservatism With Leverage As A Moderating Variable," Cogent Bus. Manag., Vol. 7, No. 1, 2020.

[23] Y. G. Shan, "Managerial Ownership, Audit Firm Size, And Audit Fees: Australian Evidence," J. Int. Accounting, Audit. Tax., Vol. 35, Pp. 18-36, 2019.

[24] R. Aulia, "Pengaruh Struktur Kepemilikan Manajerial, Struktur Kepemilikan Institusional, Ukuran Perusahaan Dan Leverage Terhadap Konservatisme Akuntansi (Studi Pada Perusahaan Makanan Dan Minuman Yang Terdaftar Di Bursa Efek Indonesia Tahun 2011-2014) Oleh:," Jom Fekon, Vol. 3, No. 1, Pp. 2357-2371, 2016.

[25] D. P. Brilianti, "Faktor-Faktor Yang Mempengaruhi Penerapan Konservatisme Akuntansi Perusahaan," Account. Anal. J., Vol. 2, No. 3, Pp. 268-275, 2013.

[26] S. Chava, "Debt Covenants And Corporate Governance," Annual Review Of Financial Economics, Vol. 11. Pp. 197-219, 2019.

[27] Z. Chen, "Litigation Risk And Debt Contracting: Evidence From A Natural Experiment," J. Law Econ., Vol. 63, No. 4, Pp. 595-630, 2020.

[28] Fatmariani, "Pengaruh Struktur Kepemilikan, Debt Covenant Dan Growth Opportunities Terhadap Konservatisme Akuntansi Pada Perusahaan Manufaktur Yang Terdaftar Di Bursa Efek Indonesia," J. Akunt., Vol. 1, Pp. 1-22, 2013.

[29] Q. T. Tran, "Creditors And Dividend Policy: Reputation Building Versus Debt Covenant," Eur. Res. Manag. Bus. Econ., Vol. 25, No. 3, Pp. 114-121, 2019.

[30] D. A. Nugroho, "Pengaruh Struktur Kepemilikan Manajerial, Debt Covenant, Tingkat Kesulitan Keuangan Perusahaan, Dan Risiko Litigasi Terhadap Konservatisme Accounting," J. Account., Vol. 1, No. 1, Pp. 1-13, 2012.

[31] B. H. Kim, "Debt Covenant Slack And Ex-Post Conditional Accounting Conservatism," Account. Bus. Res., Vol. 50, No. 2, Pp. 111-134, 2020.

[32] H. Dong, "Litigation Risk And Corporate Voluntary Disclosure: Evidence From Two Quasi-Natural Experiments," Eur. Account. Rev., Vol. 28, No. 5, Pp. 873-900, 2019.

[33] J. Malm, "Litigation Risk And Working Capital," Manag. Financ., Vol. 45, No. 1, Pp. 88-102, 2019.

[34] N. N. Lucky, "Pengaruh Risiko Litigasi, Investment Opportunity Set, Growth Opportunities, Dan Financial Distress Terhadap Konservatisme Akuntansi," Perbanas Institutional Repos., Pp. 1-20, 2019. 
[35] M. S. Lestari, "Pengaruh Tingkat Kepemilikan Manajerial, Debt Covenant Dan Risiko Litigasi Terhadap Konservatisme Akuntansi Yang Terdaftar Di Bei," Jurnal, P. 14, 2016.

[36] W. Wu, "Litigation Risk And Firm Performance: The Effect Of Internal And External Corporate Governance," Corp. Gov. An Int. Rev., Vol. 28, No. 4, Pp. 210-239, 2020.

[37] J. F. Houston, "Litigation Risk And Voluntary Disclosure: Evidence From Legal Changes," Account. Rev., Vol. 94, No. 5, Pp. 247-272, 2019.

[38] W. Wang, "Real Earnings Manipulation And Future Performance: A Revisit Using Quarterly Data Of Firms With Debt Covenants," Rev. Financ. Econ., Vol. 38, No. 1, Pp. 76-96, 2020.

[39] E. Suryandari And R. E. Priyanto, "Pengaruh Risiko Litigasi Dan Tingkat Kesulitan Keuangan Perusahaan Terhadap Hubungan Antara Konflik Kepentingan Dan Konservatisme Akuntansi," J. Akunt. Dan Investasi, Vol. 12, No. 2, Pp. 161-174, 2012.

[40] D. S. Abbas, T. Ismail, M. Taqi, And H. Yazid, "Determinants Of Enterprise Risk Management Disclosures: Evidence From Insurance Industry," Accounting, Vol. 7, No. 6, Pp. 1331-1338, 2021.

[41] A. Chariri And I. Ghozali, "Teori Akuntansi," Semarang Badan Penerbit Univ. Diponegoro, 2007.

[42] R. L. Watts Et Al., “Accounting Horizons," Vol. 17, No. 3, Pp. 207-221, 2003.

[43] C. Hu, "Managerial Risk Incentives And Accounting Conservatism," Rev. Quant. Financ. Account., Vol. 52, No. 3, Pp. 781-813, 2019.

[44] M. Cha, K. Hwang, And Y. Yeo, "Relationship Between Audit Opinion And Credit Rating: Evidence From Korea," J. Appl. Bus. Res., Vol. 32, No. 2, 2016.

[45] N. Sultana, "Earnings Conservatism And Audit Committee Financial Expertise," Account. Financ., Vol. 55, No. 1, Pp. 279-310, 2015.

[46] J. Wibowo And M. Machfoedz, "Implikasi Konservatisme Dalam Hubungan Laba-Return Dan Faktor-Faktor Yang Mempengaruhi :: Studi Empiris Pada Perusahaan-Perusahaan Manufaktur Di Bursa Efek Jakarta Periode Tahun 1995-1996,” Universitas Gadjah Mada, 2014.

[47] G. A. Feltham And J. A. Ohlson, "Valuation And Clean Surplus Accounting For Operating And Financial Activities*," Contemp. Account. Res., Vol. 11, No. 2, Pp. 689-731, Mar. 1995.

[48] J. Chen, "Dynamic Contract Design For Systemic Cyber Risk Management Of Interdependent Enterprise Networks," Dyn. Games Appl., 2020.

[49] Y. Kim Et Al., "Publisher Correction: Malaria Predictions Based On Seasonal Climate Forecasts In South Africa: A Time Series Distributed Lag Nonlinear Model," Sci. Rep., Vol. 10, No. 1, P. 2229, Dec. 2020

[50] E. F. Brigham And L. C. Gapenski, Intermediate Financial Management. Fort Worth: The Dryden Press, 1993.

[51] P. Anike Geovani, "Pengaruh Kesulitan Keuangan, Risiko Litigasi, Dan Leverage Terhadap Konservatisme Akuntansi,” Jom Fekon, Vol. 4, No. 1, Pp. 1337-1350, 2017.

[52] A. Nasir, E. Ilham, And V. I. Utara, "Analisis Pengaruh Good Corporate Governance Terhadap Kualitas Sustainability Report (Studi Empiris Pada Perusahaan Di Indonesia Periode Tahun 20112012)," J. Ekon., Vol. 22, No. 1, Pp. 65-84, 2014.

[53] A. N. D. A. Putra And P. V. Lestari, "Pengaruh Kebijakan Dividen, Likuiditas, Profitabilitas Dan Ukuran Perusahaan Terhadap Nilai Perusahaan,” E-Jurnal Manaj. Unud, Vol. 5, No. 7, Pp. 4044 4070, 2016. 